\title{
İş Sağlığı ve Güvenliği Uygulamalarının İş Doyumuna Etkisi: Çalışma Yaşamı Kalitesinin Aracılık Rolü
}

\author{
DOI: $10.26466 /$ opus. 892070
}

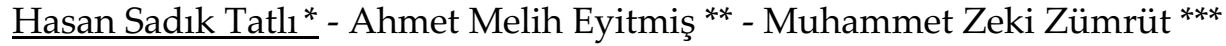 \\ * Araş. Gör., Beykent Üniversitesi, İ̈BF, İstanbul/Türkiye \\ E-Posta: hasantatli@beykent.edu.tr \\ ORCID: $\quad$ 0000-0003-1918-3188 \\ ** Dr. Öğr. Üyesi, Kahramanmaraş Sütçü İmam Üniversitesi, İ̈BF, Kahramanmaraş/Türkiye \\ E-Posta: a melih@hotmail.com ORCID: 0000-0003-1236-7689 \\ *** Dr. Öğr., Kahramanmaraş Sütçü İmam Üniversitesi, SBE, Kahramanmaraş/Türkiye \\ E-Posta: zekizumrut@hotmail.com ORCID: 0000-0002-3284-2419
}

Öz

\begin{abstract}
Araştırmanın amacı, maden işletmelerindeki iş sağhlğı ve güvenliği uygulamalarının çalışanların iş doyumlarına etkisinde çalışma yaşamı kalitesinin aracılık rolünün tespit edilmesidir. Kütahya'daki bir maden işletmesinde çalışan 215 işçi araştırmanın örneklemini oluşturmaktadır. Verilerin analizi için SPSS 25 paket programı ve SPSS Process 2.16 makrosu kullanılmıştır. Verilerin toplanmasında anket formları kullanılmıştır. Örneklem tekniği olarak basit tesadüfi örnekleme tekniği kullanılmıştır. Araştırmanın sonuçlarına göre, madenlerde uygulanan iş săglı̆̆ı ve güvenliği uygulamaları çalışanların yaşam doyumunu ve çalışma yaşamı kalitesini arttırmaktadır. Son olarak, iş sağhlğı ve güvenliği uygulamalarının çalışanların iş doyumunu arttırmasında çalışma yaşamı kalitesinin aracılık rolünün olduğu da tespit edilmiştir. Işs sağlh̆̆l ve güvenliği uygulamaları kapsamında çalışma yaşamı kalitesi oluşturduğunda çalı̧anların iş doyumlarının da artması beklenmektedir. Araştırma, maden işletmesinde çalışan bireyler ile sinırlıdır. Ayrıca çalışma nicel tekniklerle gerçekleştirilmiş ve verilerin normal dağılımı sağladığı varsayılmışıır. İş sağhlğı ve güvenliği uygulamaları çalışma yaşamı kalitesini arttırdığında çalışanların iş doyumları arttığı sonucu ve bu araştırmanın alanyazındaki diğer araştırmalardan ayrılmasını sağlamaktadır.
\end{abstract}

Anahtar Kelimeler: $\quad$ İş Sağhlı̆̆ı Ve Güvenliğ̈i, Çalışma Yaşamı Kalitesi, İş Doyumu. 


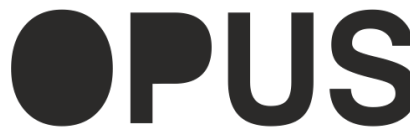

Uluslararası Toplum Araştırmaları Dergisi International Journal of Society Researches
E-ISSN : 2528-9535

YIl Year: 11

Cilt Volume: 18

Sayı Issue :Yönetim ve Organizasyon Özel Sayısı

Temmuz July 2021

Makalenin Geliş Tarihi Received Date: 10/03/2021

Makalenin Kabul Tarihi Accepted Date: 21/04/2021

\title{
The Effect of Occupational Health and Safety Practices on Job Satisfaction: The Mediator Role of Quality of Work Life
}

\begin{abstract}
The study aims to determine the mediating role of working life quality in the effect of occupational health and safety practices in mining enterprises on employees' job satisfaction. 215 workers working in a mining enterprise in Kütahya constitute the sample of the study. SPSS 25 package program and SPSS Process 2.16 macro were used for data analysis. Questionnaire forms were used for data collection. A simple random sampling technique was used as the sampling technique. According to the study results, occupational health and safety practices applied in mines increase the life satisfaction and working life quality of the employees. Finally, it has been determined that occupational health and safety practices have an intermediary role in the quality of working life in increasing employees' job satisfaction. Employees' job satisfaction is expected to increase when occupational health and safety practices create quality work life. The research is limited to individuals working in the mine operation. Also, the study was carried out with quantitative techniques, and it was assumed that the data provided a normal distribution. The result of the increase in employees' job satisfaction when occupational health and safety practices increase the quality of working life makes this study different from other studies in the literature.
\end{abstract}

Keywords: Occupational health and safety, Quality of work life, Job satisfaction 


\section{Giriş}

Günümüzde inşaat, madencilik ve ağır makine sanayi iş sağlığı ve güvenliği açısından yüksek riskli sektörlerin başında gelmektedir. Ayrıca maden işletmelerinde uygulanan iş sağlığ 1 ve güvenliği uygulamalarının yeterince uygun olmaması, çalışanların eksiklikleri, organizasyonlarda meydana gelen eksiklikler maden işletmelerinde iş kazaları ve meslek hastalıklarının artmasına neden olmaktadır. Türkiye'de 2014 yılında Manisa ilinin Soma ilçesinde yaşanan ve 301 kişinin ölümüyle sonuçlanan maden ocağı kazasından sonra iş sağlı̆̆1 ve güvenliği uygulamaları hukuki ve teknik anlamda ivme kazanmıştır. Bununla birlikte iş sağlığ ve güvenliği uygulamaları birçok işletmede uygulanmaktadır. Ancak söz konusu uygulamaların çalışanların çalışma hayatlarında nasıl bir kalite artışı sağladığı, bunun çalışanları ne kadar tatmin ettiği önemli bir probleme dönüşmektedir. Öyle ki; maden gibi zorlu çalışma ortamlarında iş sağlığı ve güvenliği uygulamalarının çalışanların çalışma yaşamı kalitelerini arttırdığında, çalışanların iş doyumlarının da artması beklenebilir. Buna göre, iş sağlığı ve güvenliği ile ilgili yukarıda bahsedilen sorunlardan hareketle araştırmanın sorusu; "İş sağhlğı ve güvenliği çalışmalarının iş doyumuna etkisinde çalışma yaşamı kalitesinin rolü var mıdır?" şeklinde oluşturulmuştur. Araştırmanın amacı ise; madenlerdeki iş sağlığg ve güvenliği uygulamalarının çalışanlardaki iş doyumuna etkisinde çalışma yaşam kalitesinin aracılık rolünün ölçülmesidir. Araştırmanın amacına bağlı olarak elde edilecek sonuçlar, çalışanların iş sağlığı ve güvenliği algılarının iş doyumlarına etkisi ve buna bağlı olarak çalışma yaşamı kalitesinin rolüne 1şık tutması açısından önem taşımaktadır. Araştırma bulgularının elde edilmesinde bazı varsayımlara dayanılmaktadır. Bunlardan ilki nicel tekniklerin maden çalışanlarının iş doyumlarını etkileyen faktörleri açıklama gücünün olduğudur. Ayrıca çalışmada kullanılan analizler (aracılık analizleri ve korelasyon analizi) normal dağılım varsayımına sahiptir. Çalışma kapsamında; iş sağlı̆̆ ve güvenliği (ISG),çalışma yaşamı kalitesi (ÇYK) ve iş doyumu (ID) kavramları incelenmektedir. 


\section{Çalışmanın Kavramsal Çerçevesi}

İşletmeler çalışma hayatına başlarken beş temel üretim faktörünü bir araya getirerek müşterilerin beklentilerini karşılamaya çalışırlar. Her bir üretim faktörünün konumu, göreceli olarak içerisinde bulunulan koşullara göre farklılık göstermektedir. Günümüze kadar farklı dönemlerde girişimcilik, teknoloji, sermaye önem kazanırken, bazı dönemler ise hammadde son derece önemli hale gelmiş, hatta söz konusu faktörler işletmeler arasında rekabet unsuru haline gelmiştir (Şimşek ve Çelik, 2016). Son yıllarda çalışanların önemi işletmeler için daha çok artmakta ve bununla alakalı olarak, devletler ve uluslararası kuruluşlar (ILO, $\mathrm{WHO}, \mathrm{AB}, \mathrm{vb}$.) birçok düzenleme yapmaktadır. Tüm bunların yanında çalışanların bedensel ve ruhsal sağliklarının korunması işletmeler adına önem kazanmaktadır. Teknolojinin ilerlemesiyle birlikte İSG uygulamalarına yönelik kanunlar ve düzenlemelerde yer alan eksiklikler giderilmeye başlanmıştır.

İş sağlı̆̆ ve güvenliği: İSG, çalışanların görevlerini gerçekleştirdikleri ortamdaki fiziki koşullardan kaynaklı olarak maruz kaldıkları mesleki riskler ve sağlık sorunlarının tamamen ortadan kaldırılması ya da en aza indirilmesi şeklinde tanımlanabilir (Balkır, 2012). İşörenler çalışma hayatları boyunca mal ve hizmet üretmek amacıyla kanunlarla belirlenmiş çalışma saatleri süresince işyerinde kalmaktadır. Çalışan, çalışma koşullarının getirdiği zorlukların yanında biyolojik, toksik ve radyasyona bağlı oluşabilecek mesleki hastalıklarla da mücadele etmektedir. İSG uygulamaları ile çalışanlar, yasal otoriteler ve işverenler; iş kazaları ve meslek hastalıklarını daha ortaya çıkmadan önlemeye çalışmaktadırlar (Akkaya, 2017). Endüstri devrimi İSG ile ilgili milat kabul edilmektedir (Biçerli, 2019). İSG ile ilgili yapılan çalışmalar gelişen teknolojilere bağlı olarak sürekli değişmektedir. Gerek yapılan bilimsel çalışmaların sonuçları, gerekse yeni üretim teknikleri sebebiyle meydana gelen mesleki hastalıklar yeni düzenlemelerin yapılmasını zorunlu hale getirmektedir.

İSG ile ilgili Türkiye'de çıkarılan 6331 sayılı kanuna birlikte; çalışanların meslek hastalıkları ve iş kazası risklerine karşı korunmasında işverenlere önleme görevleri yüklenmiştir (Karaahmetoğlu, 2019). Bu bağ- 
lamda işveren, kendine bağlı olan çalışanların ve alt işverenlerinin çalışanlarını da korumakla sorumlu hale getirilmiştir.

Çalışma yaşamı kalitesi: çalışanların iş yerinde sağlıklı bir şekilde faaliyet gösterebilmeleri için desteklenmesi, çalışanların iş için önemli olduğu farkındalığının oluşturulması, yeteneklerini fark etmelerinin sağlanması, yeteneklerinin geliştirilmesine imkân verecek iş ortamının sağlanması olarak tanımlanabilir (Erdem ve Kaya, 2013). Çalışma yaşamı kalitesinin arttırılması, çalışanların iş doyumlarının, yaşam doyumlarının boş zaman aktivitelerinin ve ekonomik refahlarının da artmasını sağlamaktadır (Aydın vd., 2011; Altay ve Turunç, 2018). İş yaşamından sağlanan olumlu katkılar, iş doyumuna ve diğer yaşam boyutlarındaki doyuma katkıda bulunmaktadır.

İş doyumu: alanyazında sıklıkla çalışılan ve birçok farklı boyutla ilişkisi incelenen temel işletmecilik boyutlarından birisidir. Çalışanlar işle ilgili gereksinimlerinin işletmeler tarafından karşılandığı sürece yeterli doyum seviyesine ulaşmaktadırlar (Yıldız vd., 2003, s.34). İş doyumu kapsam olarak işin bütün yönleri hakkındaki tutumları kapsamaktadır. Öyle $\mathrm{ki}$; iş doyumunun oluşması için, işin çalışan için her açıdan tatmin edici olması gerekmektedir. Aksi takdirde iş doyumundan söz etmek zor olacaktır (Kırel, 1999, s.118). Bu noktada iş doyumu; çalışanların işlerinden duyduğu mutluluğu ifade eder (Öngel, 2019; Karcioğlu ve Bakan, 2016).

\section{Kavramlar Arası İlişkiler ve Hipotez Geliştirme}

Karcıoğlu ve Bakan (2016) tarafından Erzurum ilindeki Yüksek Öğrenim Kredi ve Yurtlar kurumunda çalışmakta olan 101 görevli ile yapılan araştırmada, İSG uygulamaları ile iş tatmini arasındaki ilişkilerin tespit edilmesi amaçlanmıştır. Araştırma sonucunda İSG uygulamaları ile iş doyumu arasında yüksek düzeyde ilişki olduğu tespit edilmiştir. Ayrıca yaş ve cinsiyetin iş doyumu açısından anlamlı farklılıklara neden olduğu sonucuna, cinsiyetin de İSG uygulamalarını algılama açısından anlamlı farklılıklara neden olduğu sonucuna ulaşılmıştır. Çınar ve Gündoğdu (2019) tarafından çimento ve tekstil işletmelerinde çalışanların İSG alg1ları ile iş doyumları ve örgütsel bağlılıkları arasındaki ilişkiler incelen- 
miştir. Araştırma kapsamında çimento işletmesinde çalışan 115 kişiden, tekstil işletmesinde çalışan 83 kişiden anket verisi toplanmıştır. Araştırma sonucunda İSG uygulamaları ile iş doyumu arasında orta düzeyde ve pozitif yönde, İSG uygulamaları ile örgütsel bağlılık arasında orta düzeyde ve pozitif yönde anlamlı ilişkiler olduğu sonucuna ulaşılmıştır. İSG uygulamalarının iş doyumu üzerindeki etkilerini inceleyen çok sayıda çalışmaya rastlanmaktadır (Umutlu ve Karcıŏglu, 2021; Tatlıcan, ve Çögenlin, 2020; Bilgin vd., 2019; Yıldırım vd., 2015; Saraç, 2016; Yusuf vd., 2012; Gamal vd., 2018). Çalışmalarda genel olarak İSG uygulamalarının çalışanların iş doyumlarını arttırdığı yönünde bulgulara ulaşılmıştır. Yukardaki bilgiler ışığında hipotezler şu şekildedir;

\section{H1: İş sağlığı ve güvenliği uygulamaları iş doyumunu pozitif yönde etki- ler.}

Turunç vd. (2010) tarafından üniversitelerdeki öğretim elemanlarının çalışma yaşamı kalitesinin adalet, iş doyumu, iş stresi ve işten ayrılma niyetlerine etkisinin tespit edilmesi amaçlanmıştır. Araştırma kapsamında 106 öğretim elemanından anket tekniği ile veri toplanmıştır. Verilerin analizi sonucunda; çalışma yaşamı kalitesinin çalışanların adalet algısı, iş doyumunu arttırırken çalışanların stres düzeylerini azalttığı sonucuna ulaşılmıştır. Ayrıca, iş doyumunun artmasının işten ayrılma niyetini azalttığı, iş stresinin artmasının ise işten ayrılma niyetini arttırdığı sonucuna ulaşılmıştır. Demir Erbil ve Çopur (2018) tarafından Ankara ilindeki 150 çalışanın zaman yönetimleri, çalışma yaşamı kaliteleri ve iş doyumları arasındaki ilişkiler incelenmiştir. Araştırma sonucunda; çalışanların çalışma yaşamı kalitesi ile iş doyumları arasında anlamlı ilişkiler olduğu sonucuna ulaşılmıştır. Bunun yanında, çalışanların zaman yönetimleri ile çalışma yaşamı kaliteleri arasında da anlamlı ilişkiler olduğu sonucuna ulaşılmıştır. Aksoy Zor (2019) tarafından öğretmenlerin çalışma yaşamı kaliteleri, mutsuzluk düzeyleri, iş doyumları ve tükenmişlik düzeyleri arasındaki ilişkilerin tespit edilmesi amaçlanmıştır. Araştırma sonucunda iş doyumu ile çalışma yaşamı kalitesi arasında yüksek düzeyde ve pozitif yönde ilişkilerin olduğu görülmüştür. Yukarıda yer verilen araştırmalar ve alanyazında yer alan araştırmaların sonuçları incelendiğinde, çalışma yaşamı kalitesi ile iş doyumu arasındaki pozitif 
yönde ilişki olduğu görülmektedir. Söz konusu çıkarımdan hareketle oluşturulan hipotez şu şekildedir;

\section{H2: Çalışma yaşamı kalitesi algısı iş doyumunu pozitif etkiler.}

İş yerlerindeki İSG uygulamalarının ve yaşam kalitesinin arttırılması çalışanların verimliliklerinin arttırılması açısından oldukça önemlidir. İSG uygulamaları çalışanın yaşam kalitesi ve iş doyumlarını sağlamada önemli bir unsura dönüşmektedir. Bu yüzden iş yerlerinde İSG yönetim ve kontrol sistemlerinin etkin olarak kullanılması gerekmektedir (Marşap 2007: 634). Saraji ve Dargahi (2006) tarafından Tahran Tıp Bilimleri Üniversite Hastanelerindeki çalışanların yaşam kalitelerini etkileyen olumlu ve olumsuz tutumların ölçülmesi amaçlanmıştır. Bu bağlamda 15 hastanede 908 çalışana anket uygulanmıştır. Araştırmada işyerlerindeki İSG uygulamalarının çalışanların çalışma yaşamı kalitesini arttıran bir faktör olduğu bulgusuna ulaşmıştır. Erdem ve Kaya (2013) tarafından otelcilik sektöründeki çalışanların çalışma yaşamı kalitesini etkileyen faktörlerin tespit edilmesi amaçlanmıştır. Araştırma sonucunda iş yerinin fiziki çalışma koşulları, çalışma süreleri, teknoloji kullanım düzeyleri, eğitim olanakları ve iş-yaşam dengesinin çalışanların çalışma yaşama kalitesi açısından önemli unsurlar olarak belirlenmiştir. Dayan ve Öngel (2016) tarafından yapılan çalışmada ise çalışanların ergonomik, psikososyal eksikliklerin giderilmesinin, onların ruhsal ve bedensel bütünlüklerini koruma açısından gerçekleştirilen organizasyonel çalışmaların çalışanların refahını arttıracağı sonucuna ulaşılmıştır. İSG uygulamalarının çalışanların çalışma yaşamı kalitesi üzerinde olumlu yönde etkisi olduğu alanyazındaki çalışmalarda tespit edilmiş durumdadır. Ancak ulaşılan çalışmaların madencilik alanında incelenmemiş olması, madenlerde çalışanların İSG algılarının nasıl gerçekleştiği ve bu algıların çalışma yaşamı kalitesini nasıl etkilediğinin tespit edilmesini gerektirmektedir. Aksi halde ulaşılan kanılar madencilik sektörü için çıkarımsal kalacaktır. Bu düşünceden hareketle oluşturulan hipotez aşağıdaki gibidir;

H3: İş să̆lı̆̆ı ve güvenliği uygulamaları çalışma yaşamı kalitesini pozitif yönde etkiler. 
İSG uygulamalarıyla çalışanın işyerinde maruz kalabileceği iş kazası ve meslek hastalıklarını azaltması/önlemesi hedeflenmektedir. İşyerinde oluşabilecek olumlu iklimin çalışanın iş doyumunu arttıracağı yönünde kanıya ulaşılmaktadır. İSG uygulamalarının çalışanların çalışma yaşamı kalitelerine olumlu yönde katkıda bulunduğu Marşap (2007), Saraji ve Dargahi (2006) ve Erdem ve Kaya (2013) tarafından yapılan çalışmalar sonucunda tespit edilmiştir. Çalışma yaşamı kalitesinin artmasının çalışanların iş doyumlarını arttırdığı yönündeki bulgular ise; Turunç vd. (2010), Demir Erbil ve Çopur (2018), Aksoy Zor (2019) tarafından yap1lan çalışmalar sonucunda elde edilmiştir. Bahsi geçen çıkarımların bir bütün olarak anlam ifade edebilmesi olması için İSG uygulamalarının çalışanların iş doyumlarını arttırıyor olması gerekmektedir. Karcıŏlu ve Bakan (2016), Çınar ve Gündoğdu (2019), Umutlu ve Karcıoğlu (2021) gibi araştırmacılar tarafından yapılan çalışmalarda İSG uygulamalarının çalışanların iş doyumlarını arttırdığı sonucuna ulaşılmıştı. Çalışma sonuçları genel olarak yorumlandığında; iş yerlerinde uygulanan İSG uygulamalarının çalışma yaşamı kalitesini arttırdığı, çalışma yaşamı kalitesi artan çalışanların ise iş doyumlarının arttığı çıkarıma ulaşmak mümkündür. Öyle ki; bu araştırma kapsamında; işyerlerinde uygulanan İSG uygulamalarının çalışma yaşamı kalitesini arttırdığı durumda çalışanların yaşam doyumunun da artacağı düşünülmektedir. Çıkarımın test edilebilmesi için oluşturulan hipotezler şu şekildedir;

$H_{4}$ : Çalışma yaşamı kalitesi iş sağglığı ve güvenliği uygulamaları ve iş doyu$m u$ arasındaki ilişkiye aracılık eder.

$H_{4 a:}$ Çalışma yaşamı kalitesi güvenlik için kişisel motivasyon ve iş doyumu arasindaki ilişkiye aracilik eder.

$H_{4 b}$ : Çalışma yaşamı kalitesi olumlu güvenlik uygulaması ve iş doyumu arasindaki ilişkiye aracilı eder.

$H_{4 c:}$ Çalışma yaşamı kalitesi fatalizm (kadercilik) ve iş doyumu arasındaki ilişkiye aracilık eder.

Hud: Çalışma yaşamı kalitesi risk gerekçesi ve iş doyumu arasındaki ilişkiye aracilik eder.

$H_{4 e}$ : Çalışma yaşamı kalitesi iyimserlik ve iş doyumu arasındaki iliş̧iye aracllik eder.

$H_{4 f}$ Çalışma yaşamı kalitesi güvenlik algısı ve iş doyumu arasındaki ilişkiye aracilik eder. 


\section{Yöntem}

Araştırmanın bu bölümünde; araştırmada kullanılan teknikler, araştırmanın verilerinin toplanması, ölçüm araçlarının özellikleri, örneklemin belirlenmesi, araştırmanın hangi amaçla yapıldığı ve elde edilecek sonuçların neden önemli olduğu hakkında bilgiler sunulmaktadır.

\section{Araştırmanın Amacı ve Önemi}

İnsan hayatındaki hızlı değişimler tüm alanlarda da olduğu gibi iş hayatına da etki etmektedir. Çalışanlar artık diğer işletmelerde, ülkelerde, ne tür gelişmeler olduğundan hızlı şekilde haberdar olmakta ve diğerlerinde gerçekleşen yenilikleri kendi çalışma ve yaşam alanlarında da talep etmektedir. Öyle ki; endüstri devriminden sonra bilimsel açıdan incelenmeye başlanan iş hayatında, özellikle Klasik Yönetim Yaklaşımlarının benimsendiği dönemlerde (Koçel, 2015) çalışanların ekonomik insanlar oldukları, ücretlerinin yeterince arttırılmasının onların motivasyonunu da sağlayacağı düşüncesi yaygın bir görüştü. Ayrıca bu dönemde İSG (güvenlik) konusunun yönetim açısından önemli hale geldiği görülmektedir. Ancak insan unsurunun önem kazandığı modern, modern sonrası yaklaşımlar çalışanların örgütün önemli birer paydaşı olmasını sağlamıştır. Çalışanın örgüt içinde önemli bir yer edinmesi ile birlikte iş sağlığ 1 güvenliği gibi konulara olan yaklaşımlar da değişiklik göstermiştir. İşte bu noktada İSG uygulamaları örgütlerde uygulanış şekillerinin çalışanların iş yerlerindeki çalışma yaşamlarının kalitesini arttırdığı zaman, çalışanlar işlerinden doyum elde edebileceği, aksi takdirde iş sağlığı ve güvenliği uygulamalarının çalışanlar ve örgüt tarafından anlamını yitireceği düşüncesi öne çıkmaktadır. Yani, sadece prosedürleri yerine getirmek için uygulanan iş sağllğg ve güvenliği aktivitelerinin çalışanlara ve sonuçta örgütlere yeterli fayda sağlamayacağı düşünülmektedir. Söz konusu düşüncelerden hareketle iş yerlerinde uygulanmakta olan İSG uygulamalarının iş doyumuna etkisinde çalışma yaşamı kalitesinin aracılık rolünün etkisinin tespit edilmesi amaçlanmaktadır. Araştırma maden işletmelerinde gerçekleştirilmektedir. Maden işlerinin risk açısından oldukça kritik olması, çalışanların iş doyumlarını sağlayacak faktörlerin kısıtlı olması ve İSG uygulamalarının çalışanların çalışma yaşamı kalite- 
sini arttırma açısından diğer işlerden farklı olacağı düşüncesi ile araştırmanın maden işletmelerinde yapılmasına karar verilmiştir. Elde edilecek sonuçlar, modern sonrası yönetim çalışmalarına iş sağlığı ve güvenliği gibi Klasik Dönem araştırma konusunun yeniden ve farklı açlardan ele alınması, İSG uygulamalarının göreceli farklı etkilerinin belirlenmesi, riskli sektörler açısından araştırma motivasyonu oluşturması açısından önemli olabilecektir. Bunun yanında yüksek riskli alanlardaki İSG uygulamalarının çalışanlara ne düzeyde refah sağladığını tespit etme açısından elde edilecek bulgular önem taşımaktadır.

\section{Araştırmanın Kavramsal Modeli}

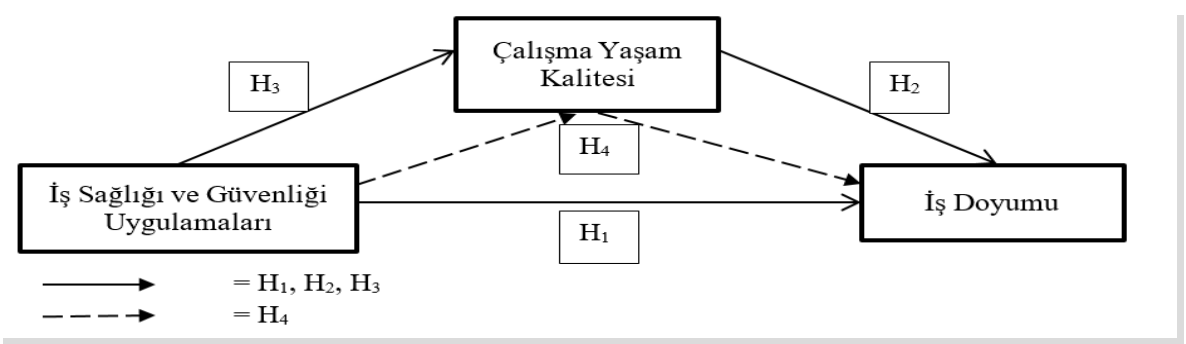

Şekil 1. Araştırmanın Kavramsal Modeli

Araştırmanın kavramsal modeli Şekil 1'de yer almaktadır. Şekilde yer alan değişkenlerin rolleri ise şu şekildedir; iş sağlığı ve güvenliği uygulamaları araştırmanın bağımsız (x) değişkeni, çalışma yaşamı kalitesi $\operatorname{aracı}(\mathrm{m})$ değişken (mediyatör) ve iş doyumu bağımlı (y) değişkendir.

\section{Araştırmanın örneklemi}

İş kazaları hakkında Amerika Birleşik Devletlerinde çalışmalar yapmakta olan "National Safety Council" tarafından sunulan araştırma bulgularına göre iş kazalarının \%63'ü insan ve işyerinde kullanılan araçların etkileşiminden kaynaklanmaktadır (Şimşek vd. 2020). Yine benzer bir araştırma raporuna göre ise, çalışanların iş yerindeki mekanik unsurlarla olan etkileşimleri kazaların \%95'ine neden olmaktadır. Maden alanında yapılan incelemede ise iş kazalarının oranı \%10,4 olarak gerçekleşmektedir (TÜIK, 2013). Bu düzeyde risk taşıyan maden işletmelerinin araştır- 
manın özelinde incelenmesi, iş sağlığı ve güvenliği uygulamaları açısından önemli görülmüştür. Bu bağlamda araştırmanın evrenini maden işlerinde çalışan personeller oluşturmaktadır. Araştırmanın örneklemini Kütahya ilindeki bir maden işletmesinde çalışan kişiler oluşturmaktadır. Maden işletmesinin çalışmaya izin vermesi örneklemin bu şekilde seçiminde etkili olmuştur. Örneklemin belirlenmesinde basit tesadüfi örneklem tekniği kullanılmıştır. Her katılımcının araştırmaya eşit katılım şansının olması, katılımcıların seçimine bağlı seçme hatasını azaltmaktadır. Ayrıca örneklemin kolayca listelenebilmesi basit tesadüfi örnekleme tekniğinin diğer bir avantajıdır. Araştırma kapsamında ulaşılan 330 maden çalışanından 215 tanesinden uygun yanıt alınmıştır. Araştırmanın anket veri toplama araçlarının uygunluğunun tespiti için Beykent Üniversitesi, Sosyal ve Beşeri Bilimler İçin Yayın Etiği Kurulu'ndan 25.01.2021 tarihinde etik kurul onayı alınmıştır.

\section{Araştırmada Kullanılan Ölçekler}

Araştırma kapsamında iş sağlığı ve güvenliğii, çalışma yaşamı kalitesi, iş doyumu ölçeği ölçekleri aracılığı ile veri toplanmıştır. İş sağlığı ve güvenliği ölçeği Willamson vd. (1997) tarafından oluşturulmuştur ve ölçek 32 madde ve 6 boyuttan oluşmaktadır. Ölçeğin Türkçe formunun oluşturulmasında Atay (2006), Bayer ve Günal (2018) tarafından yapılan araştırmalardan faydalanılmıştır. Çalışma yaşamı kalitesi ölçeği Sirgy vd. (2001) tarafından oluşturulmuş ve 16 maddeden oluşmaktadır. Çalışma yaşam ölçeğinin Türkçe formu ise Taşdemir Afşar (2011) tarafından yapılan çalışmadan elde edilmiştir. Son olarak iş doyumu ölçeği Wright ve Cropanzano (1998) tarafından oluşturulan ve Rızaoğlu ve Ayyıldız (2008) tarafından Türkçeleştirilen hali ile kullanılmıştır. Ölçüm aracında 5 madde yer almaktadır. Anket soruları 7'li likert tipinde hazırlanmıştır (1=Kesinlikle Katılmıyorum, 7= Kesinlikle Katılıyorum).

\section{Araştırmanın Bulguları}

Araştırmanın bu bölümünde araştırmada kullanılan teknikler ve bulgular hakkında bilgi verilmektedir. Araştırmada sırası ile faktör ve güveni- 
lirlik analizleri, tanımlayıcı istatistikler, normal dağılım testleri, korelasyon analizi ve aracılık analizleri yapılmıştır.

\section{Faktör analizi}

Araştırmanın bu aşamasında ölçüm araçlarının faktör analizi sonuçlarına yer verilmektedir. Faktör analizinde sınır değerleri belirlemek için Hair vd. (2014) tarafından uygun görülen değerler incelenmiştir. Söz konusu değerler, KMO örneklem yeterliliği ölçümü için; 0,700, Bartlett's küresellik testi için; $p<0,05$ ve açıllanan toplam varyans için; 0,60 (yeterli) ya da 0,70 (iyi)'dir.

Tablo 1. Faktör analizi sonuçları

\begin{tabular}{llllll}
\hline Değişken & $\begin{array}{l}\text { KMO } \\
\text { örneklem } \\
\text { yeterliliği }\end{array}$ & Anlamlılık & Ki-kare & Serbestlik & $\begin{array}{l}\text { Açılanan } \\
\text { toplam } \\
\text { varyans }\end{array}$ \\
\hline İSG & 0,834 & 0,000 & 3545,558 & 496 & 68,925 \\
Çalışma yaşamı kalitesi & 0,918 & 0,000 & 2314,414 & 120 & 71,815 \\
İş doyumu & 0,697 & 0,000 & 391,446 & 10 & 78,695 \\
\hline
\end{tabular}

Tablo 1'de İSG, çalışma yaşamı kalitesi ve iş doyumu ölçüm araçlarının faktör analizi sonuçları yer almaktadır. İSG ölçeğinin KMO örneklem yeterliliği ölçümü; 0,834, Bartlett's küresellik testi; $p<0,05$ düzeyinde anlamlı ve açıklanan toplam varyansı; $\% 68,925$ olarak tespit edilmiştir. Çalışma yaşamı kalitesi ölçeğinin KMO örneklem yeterliliği ölçümü; 0,918, Bartlett's küresellik testi; $\mathrm{p}<0,05$ düzeyinde anlamlı ve açıklanan toplam varyansı; \%71,815 olarak tespit edilmiştir. İş doyumu ölçeğinin KMO örneklem yeterliliği ölçümü; 0,697, Bartlett's küresellik testi; $\mathrm{p}<0,05$ düzeyinde anlamlı ve açılanan toplam varyansı; \%78,695 olarak tespit edilmiştir. Her üç ölçeğin belirtilen sınır değerlerine yakın ve sınır değerlerinin üzerinde olması sonucunda araştırma kapsamında kullanılmasının uygun olduğunu ifade etmek mümkündür.

\section{Güvenilirlik Analizi}

Araştırmada kullanılan İSG, çalışma yaşamı kalitesi ve iş doyumu ölçüm araçlarının yeterince güvenilir olup olmadığını tespit edebilmek için 
güvenilirlik analizi gerçekleştirilmiştir. Güvenilirlik analizinde likert tipi ölçümlerde yüksek uygunluk sağlamasından dolayı Cronbach's Alpha katsayısı incelenmiştir. Cronbach's Alpha katsayısının sınır değeri için Hair vd. (2014) tarafından uygun görülen ve alanyazında kabul gören 0,70 değeri esas alınmıştır.

Tablo 2. Güvenilirlik analizi sonuçları

\begin{tabular}{lll}
\hline Değişken & Cronbach's Alpha & Madde sayısı \\
\hline İSG & 0,934 & 32 \\
Çalışma yaşamı kalitesi & 0,946 & 16 \\
İş doyumu & 0,779 & 5 \\
\hline
\end{tabular}

Tablo 2'de güvenilirlik analizi sonuçları yer almaktadır. Güvenilirlik analizi sonuçlarına göre İSG ölçeğinin Cronbach's Alpha katsayısının 0,934, çalışma yaşamı kalitesi ölçeğinin Cronbach's Alpha katsayısının 0,946 ve iş doyumu ölçeğinin Cronbach's Alpha katsayısının 0,779 olduğu görülmüştür. Ayrıca İSG ölçeğinde 32 madde, çalışma yaşamı kalitesi ölçeğinde 16 madde ve iş doyumu ölçeğinde 5 madde yer almıştır. Son olarak; faktör analizi ve güvenilirlik analizi esnasında ölçeklerde yer alan herhangi bir madde araştırma kapsamı dışında bırakılmamıştır.

Tablo 3. Tanımlayıcı özellikler

\begin{tabular}{llll}
\hline Değişken & Özellik & Kişi & $\%$ \\
\hline \multirow{3}{*}{ Yaş } & 30 ve altında & 34 & 15,8 \\
& 31-40 arası & 106 & 49,3 \\
& 41 ve üzeri & 75 & 34,9 \\
\hline \multirow{3}{*}{ Eğitim } & İlköğretim & 94 & 43,7 \\
& Lise & 98 & 45,6 \\
& Üniversite & 21 & 9,8 \\
\hline \multirow{2}{*}{ Medeni durum } & Evli & 199 & 92,6 \\
& Bekar & 16 & 7,4 \\
\hline \multirow{4}{*}{ Aile geliri } & $0-2000$ & 20 & 9,3 \\
& 2001-2500 & 145 & 67,4 \\
& 2501-3000 & 20 & 9,3 \\
& 3001 ve üzeri & 28 & 13,0 \\
\hline \multirow{3}{*}{ Mesleki Tecrübe } & $0-5$ yıl & 36 & 16,7 \\
& 6-10 y1l & 94 & 43,7 \\
\hline
\end{tabular}


Araştırmaya dahil olan maden işçilerinin demografik özellikleri ile ilgili bilgiler tablo 3'ter yer almaktadır. Tabloya göre katılımcıların $\% 15,8^{\prime} \mathrm{i}$ 30 yaş ve altındaki kişilerden oluşurken katılımcıların \%49,3'ü 31-40 yaş aralığında, \%34,9'u ise 41 yaş ve üzerindeki yaş grubunda yer almaktadır. Katılımcıların \%43,7'si ilköğretim mezunu, \%45,6'sı lise mezunu ve $\% 9,8^{\prime} \mathrm{i}$ ise üniversite mezunudur. Katılımcıların \%92,6's1 evli, \%7,4'ü bekârlardan oluşmaktadır. Katılımcıların ailelerinin aylık gelir düzeyi incelendiğinde; \%9,3'ünün 2000 TL'nin altında, \%67,4'ünün 2001-2500 TL arasında, \%9,3'ünün 2501-3000 TL arasında, \%13'ünün ise 3001 TL ve üzerinde gelire sahip olduğu görülmektedir. Katılımcıların \%16,7'sinin 0-5 y1l arasinda, \%43,7'sinin 6-10 yıl arasinda, \%39,5'inin ise 11 yll ve üzerinde bir süre mesleki tecrübeye sahip olduğu görülmektedir.

Tablo 4. Değişkenlere ait tanımlayıcı istatistikler

\begin{tabular}{llll}
\hline Değişkenler & Kişi & Ortalama & Std. Sapma \\
\hline İSG & 215 & 5,5411 &, 96393 \\
Güvenlik için kişisel motivasyon & 215 & 6,3389 &, 80173 \\
Olumlu güvenlik uygulaması & 215 & 5,5425 & 1,38295 \\
Fatalizm (kadercilik) & 215 & 5,1877 & 1,46503 \\
Risk gerekçesi & 215 & 5,2353 & 1,41205 \\
İyimserlik & 215 & 5,1729 & 1,38707 \\
Güvenlik algısı & 215 & 5,2954 & 1,39764 \\
Çalışma yaşamı kalitesi & 215 & 5,2506 & 1,38408 \\
İş doyumu & 215 & 5,6335 & 1,25307 \\
\hline
\end{tabular}

Maden çalışanlarının ölçüm araçlarında yer alan maddelere verdikleri yanıtların istatistiki değerleri Tablo 4 'te yer almaktadır. Maden çalışanlarının madenlerde uygulanan İSG uygulamaları ile ilgili algılamaları olumlu düzeydedir.

Bunun yanında İSG alt boyutları açısından incelendiğinde; çalışanların güvenlik için kişisel motivasyonlarının çok yüksek düzeyde olduğu, iş yerindeki güvenlik uygulamalarının yüksek düzeyde olumlu algılandığı, çalışanlarda yüksek düzeyde kadercilik algısının da olduğu, risk algısı, iyimserlik ve güvenlik algılarının da yüksek düzeyde olduğu görülmektedir. Çalışanların çalışma yaşamı kalitesi algılarının yüksek düzeyde olduğu, iş doyumlarının ise yine yüksek düzeyde olduğu sonucuna ulaşılmıştır. Standart sapma değerleri incelendiğinde; standart sap- 
manın çok yüksek olmadığı yani ortalama değerlerin tesadüfi olmadığını ifade etmek mümkündür.

Tablo 5. Değişkenler arası ilişkiler

\begin{tabular}{|c|c|c|c|c|c|c|c|c|}
\hline & U. & 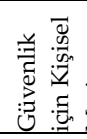 & 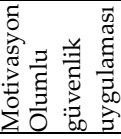 & 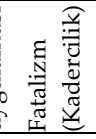 & 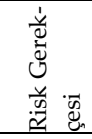 & 弟 & 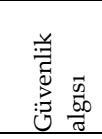 & 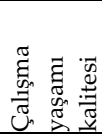 \\
\hline \multirow{3}{*}{ İSG } & Pearson Korelasyon1 & & & & & & & \\
\hline & $\begin{array}{l}\text { Anlamlılik (2- } \\
\text { Kuyruk) }\end{array}$ & & & & & & & \\
\hline & Kişi & & & & & & & \\
\hline \multirow{3}{*}{$\begin{array}{l}\text { Güvenlik için } \\
\text { Kişisel Motivas- } \\
\text { yon }\end{array}$} & Pearson Korelasyon, $500^{* *}$ & 1 & & & & & & \\
\hline & $\begin{array}{l}\text { Anlamlılik (2- } \\
\text { Kuyruk) }\end{array}$ & & & & & & & \\
\hline & Kişi & 215 & & & & & & \\
\hline \multirow{3}{*}{$\begin{array}{l}\text { Olumlu güvenlik } \\
\text { uygulaması }\end{array}$} & Pearson Korelasyon, $760^{* *}$ & ,291** & 1 & & & & & \\
\hline & $\begin{array}{l}\text { Anlamlilik (2- } \\
\text { Kuyruk) }\end{array}$ &, 000 & & & & & & \\
\hline & Kişi & 215 & 215 & & & & & \\
\hline \multirow{3}{*}{$\begin{array}{l}\text { Fatalizm (Kaderci- } \\
\text { lik) }\end{array}$} & Pearson Korelasyon, $835^{* *}$ & $265^{* *}$ &, $527^{* *}$ & 1 & & & & \\
\hline & $\begin{array}{l}\text { Anlamlılık (2- } \\
\text { Kuyruk) }\end{array}$ & ,000 & ,000 & & & & & \\
\hline & Kişi & 215 & 215 & 215 & & & & \\
\hline \multirow{3}{*}{ Risk Gerekçesi } & Pearson Korelasyon, $774^{* *}$ & $283^{* *}$ & $457^{* *}$ & $634^{* *}$ & 1 & & & \\
\hline & $\begin{array}{l}\text { Anlamlılik (2- } \\
\text { Kuyruk) }\end{array}$ & ,000 & ,000 &, 000 & & & & \\
\hline & Kişi & 215 & 215 & 215 & 215 & & & \\
\hline \multirow{3}{*}{ İyimserlik } & Pearson Korelasyon, $799^{* *}$ & $265^{* *}$ &, $527^{* *}$ & $667^{* *}$ &, $601^{* *}$ & 1 & & \\
\hline & $\begin{array}{l}\text { Anlamlılık (2- } \\
\text { Kuyruk) }\end{array}$ & ,000 & ,000 & ,000 &, 000 & & & \\
\hline & Kişi & 215 & 215 & 215 & 215 & 215 & & \\
\hline \multirow{3}{*}{ Güvenlik algısı } & Pearson Korelasyon, $746^{* *}$ & $259^{* *}$ & $382^{* *}$ & $571^{* *}$ &, $557^{* *}$ & $608^{* *}$ & 1 & \\
\hline & $\begin{array}{l}\text { Anlamlılik (2- } \\
\text { Kuyruk) }\end{array}$ & ,000 & ,000 & , 000 & ,000 &, 000 & & \\
\hline & Kişi & 215 & 215 & 215 & 215 & 215 & 215 & \\
\hline \multirow{3}{*}{$\begin{array}{l}\text { Çalışma yaşamı } \\
\text { kalitesi }\end{array}$} & Pearson Korelasyon, $683^{* *}$ &, $252^{* *}$ & $679^{* *}$ & $474^{* *}$ & $428^{* *}$ & $618^{* *}$ &, $504^{* *}$ & 1 \\
\hline & $\begin{array}{l}\text { Anlamlılık (2- } \\
\text { Kuyruk) }\end{array}$ & ,000 & ,000 & , 000 & ,000 &, 000 & ,000 & \\
\hline & Kişi & 215 & 215 & 215 & 215 & 215 & 215 & 215 \\
\hline \multirow{3}{*}{ İş doyumu } & Pearson Korelasyon, $527^{* *}$ &, $291^{* *}$ &, $593^{* *}$ & $257^{* *}$ &, $355^{* *}$ & $433^{* *}$ & $392^{* *}$ & $671^{* *}$ \\
\hline & $\begin{array}{l}\text { Anlamlılık (2- } \\
\text { Kuyruk) }\end{array}$ & ,000 & ,000 & , 000 & ,000 & ,000 & ,000 & , 000 \\
\hline & Kişi & 215 & 215 & 215 & 215 & 215 & 215 & 215 \\
\hline
\end{tabular}

**. İişki 0.01 seviyesinde anlamlı (2-kuyruk).

Değişkenler arasındaki ilişkilerin tespit edilebilmesi amacı ile yapılmakta olan korelasyon analizi sonuçları Tablo 5'te yer almaktadır. Kore- 
lasyon analizi sonucunda çalışma yaşamı kalitesi ile İSG arasında yüksek düzeyde pozitif yönde ve istatistiki olarak $\mathrm{p}<0,05$ düzeyinde anlamlı bir ilişki olduğu görülmektedir. Güvenlik için kişisel motivasyon sağlama ile çalışma yaşamı kalitesi arasında düşük düzeyde, olumlu güvenlik uygulaması ve iyimserlik ile çalışma yaşamı kalitesi arasında yüksek düzeyde, kadercilik, risk gerekçesi ve güvenlik algısı ile çalışma yaşamı kalitesi arasında pozitif yönlü ve $p<0,05$ düzeyinde istatistiki olarak anlamlı ilişkiler olduğu tespit edilmiştir. İş doyumu ile İSG arasında orta düzeyde, iş doyumu ile çalışma yaşamı kalitesi arasında yüksek düzeyde pozitif yönde, $\mathrm{p}<0,05$ düzeyinde istatistiki olarak anlamlı ilişkiler tespit edilmiştir. İş doyumu ile İSG alt boyutları arasındaki ilişkiler incelendiğinde; iş doyumu ile güvenlik için kişisel motivasyon, kadercilik, risk gerekçesi ve güvenlik arasında düşük düzeyde pozitif yönde, $p<0,05$ düzeyinde istatistiki olarak anlamlı ilişkiler olduğu görülmektedir. Ayrıca iş doyumu ile olumlu güvenlik uygulamaları ve iyimserlik arasında orta düzeyde, pozitif yönde ve $\mathrm{p}<0,05$ düzeyinde anlamlı ilişkiler tespit edilmiştir. İSG alt boyutlarının arasında farklı düzeylerde, pozitif yönde ve $p<0,05$ düzeyinde anlamlı ilişkilerin olduğu görülmektedir. Elde edilen ilişkilerin istatistiki olarak anlamlı olması, değişkenlerin aracılık analizine uygun olduğunu göstermektedir.

\section{Aracılık Analizi Sonuçları (Mediyatör Analiz)}

Araştırmada İSG'nin çalışanların iş doyumlarına etkisinde çalışma yaşamı kalitesinin aracılık (mediyatör) rolü tespit edilmeye çalışılmaktadır. Aracılık rolünün tespit edilebilmesi için SPSS 25 paket programı ile bütünleşmiş şekilde çalışan SPSS Process 2.16 makrosu kullanılmıştır. Aracllık analizine geçilmeden önce değişkenler arasındaki ilişkilerin varlığ1 kontrol edilmiş ve Tablo 4'te gösterildiği üzere değişkenler arasında istatistiki olarak anlamlı ilişkilerin olduğu tespit edilmiştir. Diğer yandan verilerin normal dağılımı aracılık analizi için önem arz etmektedir. Bu nedenle normal dağılım testleri (Kolmogrov-Smirnov ve Shapiro-Wilk) yapılmıştır. Söz konusu testler sonucunda normal dağılımın $p<0,05$ düzeyinde anlamlı olmasına bağlı olarak, araştırmanın verilerinin normal dağılımı sağlamadığı sonucuna ulaşılmıştır. George ve Mallery, (2010), Tabachnick ve Fidell (2013), Hair vd. (2014) normal dağılım sosyal bilim- 
lerde anket aracılığı ile toplanan verilerde sağlamanın zor olmasından bahsetmektedir. Bu yüzden normal dağılımın varsayılması için çarpıklık ve basıklık değerlerinin incelenmesinin uygun olacağını ifade etmektedirler. Normal dağılım testleri sonucuna elde edilen çarpıklık ve basıklık değerlerinin -1,5 ile 1,5 değerleri arasında yer alması normal dağılım için yeterli görülmektedir. Söz konusu varsayıma dayanarak, bu araştırmada aracılık analizi yapılmıştır. Aracılık (mediyatör) analizi için SPSS Process 2.16 makrosu kullanılmıştır. Söz konusu makroda birçok model hazır olarak sunulmaktadır. Bu araştırma kapsamında belirlenmiş Şekil 1'deki araştırma modeli Hayes (2018) tarafından oluşturulmuş 4 numara11 model ile uyumludur. Bu nedenle aracılık analizi 4 numaralı model üzerinden gerçekleştirilmiştir. Ayrıca analizlerin yorumlanmasında Hayes (2018)'in prosedürü izlenmiştir. Aracı değişken modele dâhil edildiğinde bağımsız değişkenin bağımlı değişken üzerindeki etkisinin istatistiki açıdan tamamen anlamsız hale gelmesi tam aracılık (tam mediyatör), anlamlılığın kısmen bozulması ya da açıklama katsayısının önemli ölçüde düşmesi ise kısmi aracılık (kısmi mediyatör) etkisi olarak yorumlanmaktadır. Aracı değişkenin modele girmesinin bağımsız değişkenin bağımlı değişken üzerindeki etkisinde istatistiki açıdan bozulma oluşturmaması ve katsayıda önemli ölçüde değişme-düşüş olmaması durumunda ise aracılık etkisinden bahsedilememektedir. Aracılık etkisinin yorumlanmasında güven aralıkları kullanılmaktadır. Üst seviye güven aralığ1 (ULCI) ve alt seviye güven aralığı (LLCI) arasında sıfır noktası olması açısından değerlendirilir. Eğer ULCI ve LLCI değerleri arasında sıfır noktası bulunursa, güvenilir sonuç elde edilmediği tespit edilmiş olur (Hayes, 2018). Bunun yanında aracılık modelinin anlamlılığını test edilmesi için ise Sobel Testi kullanılır (Sobel, 1982; 1986). Sobel testinin p<0,05 düzeyinde olması, aracılık modelinin anlamlılığını ifade etmektedir. Yapılan aracılık analizleri ile ilgili sonuçlar Tablo 6'da ve Tablo 7'de yer almaktadir.

Madenlerde İSG uygulamalarının iş doyumu oluşturmada çalışma yaşamı kalitesinin aracılık rolünü tespit edebilmek için yapılan analiz sonucunda elde edilen bulgular Tablo 6'da yer almaktadır. Tabloda İSG ana boyutu üzerinden yapılan analiz sonuçları bulunmaktadır. Tablo yer alan bulgular incelendiğinde; İSG uygulamalarının iş doyumuna etkisi $\% 27,76$ olarak gerçekleşmiştir. 
Tablo 6. Aracılık analizi sonuçları

\begin{tabular}{|c|c|c|c|c|c|c|c|}
\hline \multicolumn{4}{|l|}{ Model özeti } & \multicolumn{4}{|l|}{ Model } \\
\hline Değişken & $\mathbf{r}$ & $\mathbf{r}^{2}$ & $\mathrm{p}$ & Katsayı & LLCI & ULCI & $\mathrm{p}$ \\
\hline Sabit (iş doyumu) & \multirow{3}{*}{ 6776 } & \multirow{3}{*}{ 4592 } & \multirow{3}{*}{0,0000} & 1,9360 & 1,2078 & 2,6642 & 0,0000 \\
\hline $\begin{array}{l}\text { Çalışma yaşamı } \\
\text { kalitesi }\end{array}$ & & & &, 5283 & 4049 & 6518 & 0,0000 \\
\hline İSG & & & & 1667 &,- 0106 & ,3439 & 0,0652 \\
\hline Model özeti & & & & Model & & & \\
\hline Değişken & $\mathbf{r}$ & $\mathbf{r}^{2}$ & $\mathrm{p}$ & Katsayı & LLCI & ULCI & $\mathrm{p}$ \\
\hline Sabit (iş doyumu) & \multirow{2}{*}{, 5268} & \multirow{2}{*}{ 2776 } & \multirow{2}{*}{0,0000} & 1,8385 & ,9992 & 2,6777 & 0,0000 \\
\hline İSG & & & & 6849 &, 5356 & 8341 & 0,0000 \\
\hline \multicolumn{8}{|c|}{ Aracılık testinin geçerliliği (Sobel Testi) } \\
\hline Etki & & \multicolumn{2}{|l|}{ Std. Hata } & $\mathrm{Z}$ & & \multicolumn{2}{|l|}{$\mathrm{p}$} \\
\hline, 5182 & \multicolumn{3}{|c|}{, 0723} & 7,1638 & & \multicolumn{2}{|l|}{, 0000} \\
\hline
\end{tabular}

İSG'nin iş doyumuna etkisini gösteren modele çalışma yaşamı kalitesinin eklenmesi ile birlikte iş doyumunun açıklanma düzeyi \%45,92 olarak gerçekleşmiştir. Ancak modele çalışma yaşamı kalitesinin dahil edilmesi ile birlikte İSG' nin iş doyumunu açıklama düzeyinin $0,6849^{\prime}$ dan 0,1667'ye düştüğü görülmektedir. Ayrıca anlamlılığın ise $0,0000<\mathrm{p}<0,0652$ şeklinde bozulduğu görülmektedir. Yani İSG'nin modelde anlamsız hale geldiği görülmektedir. Söz konusu değişim çalışma yaşamı kalitesi değişkeninin tam aracılık(mediyatör) rolünün olduğunu göstermektedir. Elde edilen bulgulara göre; iş güvenliği ve iş sağlığını yaşam doyumuna etkisinde çalışma yaşamı kalitesinin aracılık rolü bulunmaktadır. Araştırmada elde edilen sonuçlara göre iş sağlığı ve güvenliği uygulamalarının iş doyumu üzerinde pozitif yönde etkisi olmasından dolayı $\mathrm{H}_{1}$ hipotezi, çalışma yaşamı kalitesinin iş doyumu üzerinde pozitif yönde etkisinin olmasından dolayı $\mathrm{H}_{2}$ hipotezi, İSG uygulamalarının çalışma yaşamı kalitesi üzerindeki anlamlı etkisi ile birlikte aracılık rolünün tespit edilmesinden dolayı $\mathrm{H}_{3}$ ve $\mathrm{H}_{4}$ hipotezleri desteklenmiştir.

İş güvenliği ve iş sağlığının alt boyutları açısından yapılan aracılık analizlerinin sonuçları Tablo 7'de yer almaktadır. Aracılık analizi sonucunda güvenlik için kişisel motivasyonun iş doyumunu açıklama düzeyinin (Katsayı: 0,4552, Anlamlılık; $p<0,05$ ) anlamlı olduğu görülmektedir. Ancak çalışma yaşamı kalitesinin modele dâhil olması ile birlikte açıklama düzeyinin (Katsayı: 0,2043) önemli ölçüde düştügü, anlamlılıkta ise (p: 0,0124) kısmi bozulma olduğu görülmektedir. Sobel testi sonucu ise 
$p<0,05$ düzeyinde istatistiki olarak anlamlıdır. Bulgular doğrultusunda güvenlik için kişisel motivasyonun iş doyumuna etkisinde çalışma yaşamı kalitesinin kısmi aracılık rolünün olduğunu ifade etmek mümkündür. Bulgulara göre $\mathrm{H}_{4 a}$ hipotezi kısmen desteklenmiştir.

\section{Tablo 7. Alt boyutlar için aracılık analizleri}

\begin{tabular}{|c|c|c|c|c|c|c|c|c|}
\hline \multicolumn{4}{|l|}{ Model özeti } & \multicolumn{4}{|c|}{ Model (bağımsız değişken) } & \multirow{2}{*}{$\begin{array}{l}\text { Sobel } \\
\text { p }\end{array}$} \\
\hline Aracı Değişken & $\mathbf{r}$ & $\mathbf{r}^{2}$ & $\mathrm{p}$ & Katsayı & LLCI & ULCI & $\mathrm{p}$ & \\
\hline $\begin{array}{l}\text { Güvenlik için Kişisel } \\
\text { Motivasyon** }\end{array}$ & 6830 & 4664 & 0,0000 & 2043 & ,0446 & 3640 & 0,0124 & \multirow{2}{*}{,0003 } \\
\hline $\begin{array}{l}\text { Güvenlik için Kişisel } \\
\text { Motivasyon }\end{array}$ & 2912 & ,0848 & 0,0000 & ,4552 & ,2532 & 6571 & 0,0000 & \\
\hline $\begin{array}{l}\text { Olumlu güvenlik } \\
\text { uygulamasi }\end{array}$ & 6967 & 4854 & 0,0000 & 2308 & 1109 & ,3508 & 0,0002 & \multirow{2}{*}{0,0000} \\
\hline $\begin{array}{l}\text { Olumlu güvenlik } \\
\text { uygulaması }\end{array}$ &, 5931 & 3518 & 0,0000 & ,5374 & 4389 & 6359 & 0,0000 & \\
\hline $\begin{array}{l}\text { Fatalizm (Kaderci- } \\
\text { lik)** }\end{array}$ & 6748 & 4553 & 0,0000 & -0679 & -1650 & ,0291 & 0,1691 & \multirow[t]{2}{*}{0,0000} \\
\hline Fatalizm (Kadercilik) & 2567 & 0659 & 0,0001 & 2195 & 1079 & ,3312 & 0,0001 & \\
\hline Risk Gerekçesi*** & 6753 & 4560 & 0,0000 & 0732 &,- 0248 & 1713 & 0,1425 & \multirow{2}{*}{0,0000} \\
\hline Risk Gerekçesi & 3547 & 1258 & 0,0000 & ,3147 & ,2027 & ,4268 & 0,0000 & \\
\hline İyimserlik** & 6715 & 4510 & 0,0000 & 0268 & -0884 & 1420 & 0,6469 & \multirow{2}{*}{0,0000} \\
\hline İyimserlik & 4329 & 1874 & 0,0000 & 3910 & ,2811 &, 5010 & 0,0000 & \\
\hline Güvenlik algisi'** & 6740 & 4543 & 0,0000 & ,0648 & -0390 & 1686 & 0,2198 & \multirow{2}{*}{0,0000} \\
\hline Güvenlik algısı & ,3920 & 1536 & 0,0000 & ,3514 & ,2400 & 4628 & 0,0000 & \\
\hline
\end{tabular}

Olumlu güvenlik uygulamalarının iş doyumunu açıklama düzeyinin (Katsayı: 0,5374, Anlamlılık; $p<0,05$ ) anlamlı olduğu görülmektedir. Ancak çalışma yaşamı kalitesinin modele dâhil olması ile birlikte açıklama düzeyinin (Katsayı: 0,2308) önemli ölçüde düştüğü, anlamlılıkta ise (p: $0,0002)$ çok düşük düzeyde değişme olduğu görülmektedir. Sobel testi sonucu ise $\mathrm{p}<0,05$ düzeyinde istatistiki olarak anlamlıdır. Katsayısındaki önemli düşüş doğrultusunda olumlu güvenlik uygulamalarının iş doyumuna etkisinde çalışma yaşamı kalitesinin kısmi aracılık rolünün olduğunu ifade etmek mümkündür. Bulgulara göre $\mathrm{H}_{4 b}$ hipotezi kısmen desteklenmiştir.

Kaderciliğin iş doyumunu açıklama düzeyinin (Katsayı: 0,2195, Anlamlılık; $\mathrm{p}<0,05)$ anlamlı olduğu görülmektedir. Ancak çalışma yaşamı kalitesinin modele dâhil olması ile birlikte açıklama düzeyinin (Katsayı: 0,0697) önemli ölçüde düştüğü, anlamlılıkta ise (p: 0,1691) tamamen bo- 
zulma olduğu görülmektedir. Sobel testi sonucu ise $p<0,05$ düzeyinde istatistiki olarak anlamlıdır. Katsayısındaki önemli düşüş ve anlamlılığın istatistiki olarak bozulmasına bağlı olarak kaderciliğin iş doyumuna etkisinde çalışma yaşamı kalitesinin tam aracılık rolünün olduğunu ifade etmek mümkündür. Bulgulara göre $\mathrm{H}_{4 c}$ hipotezi desteklenmiştir.

Risk gerekçesinin iş doyumunu açıklama düzeyinin (Katsayı: 0,3147, Anlamlılık; $p<0,05)$ anlamlı olduğu görülmektedir. Ancak çalışma yaşamı kalitesinin modele dahil olması ile birlikte kaderciliğin açıklama düzeyinin (Katsayı: 0,0732) önemli ölçüde düştüğü, anlamlılığın ise (p $: 0,1425)$ tamamen bozulduğu görülmektedir. Sobel testi sonucu ise $\mathrm{p}<0,05$ düzeyinde istatistiki olarak anlamlıdır. Katsayısındaki önemli düşüş ve anlamlılığın istatistiki olarak bozulmasına bağlı olarak risk gerekçesinin iş doyumuna etkisinde çalışma yaşamı kalitesinin tam aracllık rolünün olduğunu ifade etmek mümkündür. Bulgulara göre $\mathrm{H}_{4 \mathrm{~d}}$ hipotezi desteklenmiştir.

İyimserliğin iş doyumunu açılama düzeyinin (Katsayı: 0,3910, Anlamlılık; $\mathrm{p}<0,05)$ anlamlı olduğu görülmektedir. Ancak çalışma yaşamı kalitesinin modele dahil olması ile birlikte iyimserliğin açıklama düzeyinin (Katsayı: 0,0268) önemli ölçüde düştüğü, anlamlılığın ise (p: 0,6469) tamamen bozulduğu görülmektedir. Sobel testi sonucu ise $p<0,05$ düzeyinde istatistiki olarak anlamlıdır. Katsayısındaki önemli düşüş ve anlamlılığın istatistiki olarak bozulmasına bağlı olarak iyimserliğin iş doyumuna etkisinde çalışma yaşamı kalitesinin tam aracılık rolünün olduğunu ifade etmek mümkündür. Bulgulara göre $\mathrm{H}_{4 \mathrm{e}}$ hipotezi desteklenmiştir.

Güvenlik algısının iş doyumunu açklama düzeyinin (Katsayı: 0,3514, Anlamlılık; $p<0,05)$ anlamlı olduğu görülmektedir. Ancak çalışma yaşamı kalitesinin modele dahil olması ile birlikte güvenlik algısının açıklama düzeyinin (Katsayı: 0,0648) önemli ölçüde düştüğü, anlamlılığın ise (p:0,2198) tamamen bozulduğu görülmektedir. Sobel testi sonucu ise $\mathrm{p}<0,05$ düzeyinde istatistiki olarak anlamlıdır. Katsayısındaki önemli düşüş ve anlamlılığın istatistiki olarak bozulmasına bağlı olarak güvenlik algısının iş doyumuna etkisinde çalışma yaşamı kalitesinin tam aracılık rolünün olduğunu ifade etmek mümkündür. Bulgulara göre $\mathrm{H}_{4 \mathrm{f}}$ hipotezi desteklenmiştir. Hipotezlerin desteklenme durumları genel olarak şu şekildedir; 
$H_{1}:$ İş sağhlğ̆ ve güvenliği uygulamaları iş doyumu üzerinde pozitif yönde etki eder.

Desteklendi

$\mathrm{H}_{2}$ : Çalışma yaşamı kalitesi algısı iş doyumunu pozitif etkiler.

Desteklendi

$H_{3}$ : İş sağhlı̆̆ ve güvenliği uygulamaları çalışma yaşamı kalitesini pozitif yönde etkiler.

Desteklendi

$H_{4}$ : Çalışma yaşamı kalitesi iş să̆lığı ve güvenliği uygulamaları ve iş doyumu arasındaki ilişkiye

aractlı eder.

$H_{4 a}$ : Çalı̧̧ma yaşamı kalitesi güvenlik için kişisel motivasyon ve iş doyumu arasındaki ilişkiye

Desteklendi

aracilık eder.

$H_{4 b:}$ Çalışma yaşamı kalitesi olumlu güvenlik uygulaması ve iş doyumu arasındaki ilişkiye aracılık eder.

Kısmen

Desteklendi

Kısmen

Desteklendi

$H_{4 c:}$ Çalışma yaşamı kalitesi fatalizm (kadercilik) ve iş doyumu arasındaki ilişkiye aracılık eder.

Kismen

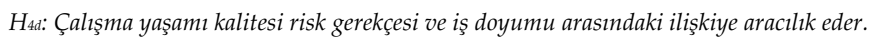

$H_{4 e}$ : Çalışma yaşamı kalitesi algısı iyimserlik ve iş doyumu arasındaki ilişkiye aracılık eder.

$H_{4 f:}$ Çalışma yaşamı kalitesi güvenlik algısı ve iş doyumu arasındaki ilişkiye aracılık eder.

Desteklendi

Desteklendi

Desteklendi

Desteklendi

\section{Sonuç}

Araştırma, madenlerde İSG uygulamalarının çalışanların iş doyumlarına etkisinde çalışma yaşamı kalitesinin aracılık rolünün tespit edilebilmesi amacıyla yapılmıştır. Araştırma sonucunda bazı bulgulara ulaşılmıştır; madenlerde uygulanan İSG uygulamalarının çalışanların yaşam doyumunu arttırmaktadır. Bunun yanında İSG uygulamaları çalışma yaşamı kalitesini de arttırmaktadır. Madenlerde uygulanan İSG uygulamalarının çalışanların iş doyumunu arttırmasında çalışma yaşamı kalitesinin aracılık rolünün olduğu tespit edilmiştir. Öyle ki; İSG uygulamaları çalışma yaşamı kalitesini sağladığı durumda çalışanların iş doyumlarının da artacağı önemli bir sonuca dönüşmektedir. Yani İSG uygulamaları maden çalışanlarının çalışma yaşamı kalitesini arttıracak düzeyde olmadiğında, çalışanların iş doyumlarının artmayacağını ifade etmek mümkündür.

Alanyazında İSG uygulamalarının maden işçilerinin iş doyumlarına etkisinde çalışma yaşamı kalitesinin aracılık rolünü inceleyen bir çalışmaya ulaşılamamıştır. Bu yüzden değişkenler arası ikili ilişkilerin kıyaslanması yapılmaktadır. Çalışma yaşamı kalitesi ile iş doyumu arasındaki ilişkilerle ilgili olarak yazında yer alan çalışmalar incelendiğinde; Karakaya Çiçek ve Çoruk (2017) tarafından yapılan çalışmada çalışma yaşamı kalitesi arasında pozitif yönde ilişki olduğu; Türkay (2015), Dhamija vd. (2019), Jaben vd. (2017) tarafından yapılan çalışmalarda da çalışma yaşamı kalitesinin iş doyumunu arttırdığı sonuçlarına ulaşılmıştır. Çalışan- 
ların İSG algıları ile iş doyumları arasındaki ilişkileri inceleyen çalışma sonuçları incelendiğinde; Bilgin vd. (2019), Çınar ve Gündoğdu (2019), Yıldırım vd. (2015) tarafından yapılan çalışmalarda iş güvenliği ve iş sağlığının iş doyumlarını arttırdığı sonucuna ulaşılmıştır. Saraji ve Dargahi (2006) tarafından yapılan araştırmada ise işyerlerindeki İSG uygulamalarının çalışanların çalışma yaşamı kalitesini arttıran bir faktör olduğu bulgusuna ulaşmıştır. Bu araştırma kapsamında elde edilen sonuçlar ve alanyazında önceki çalışmalardaki değişkenler arası ilişkileri ve nedensellik bulgularının uyumlu olduğu görülmektedir. Çalışma sonuçları ve alanyazındaki önceki çalışma sonuçları birlikte düşünüldüğünde; maden işletmelerinde uygulanan iş sağlı̆̆1 ve güvenliği prosedürlerinin çalışanlarını çalışma yaşamı kalitelerinin arttırdığı durumda, çalışanlar işlerinden doyum elde edebilecektir. Maden çalışanlarının çalışma yaşamı kalitelerini olumlu yönde yükseltmeyen İSG uygulamalarının çalışanların işlerinden doyum sağlamalarına da katkı sağlamayacağını ifade etmek mümkündür.

Araştırmada elde edilen bulgular değerlendirilirken bazı faktörler göz ardı edilmemelidir; çalışanların çok büyük kesimi asgari ücret karşılığında çalışan maden işçilerinden oluşmaktadır ve çalışanların aile boyutundaki gelirleri de çok düşük seviyededir. Bu durumdaki çalışanların iş doyumlarını etkileyen faktörleri tespit etmek için farklı tekniklerin de kullanılması uygun olabilir. Örneğin; derinlemesine görüşmeler, maden gibi çok zorlu çalışma alanlarındaki çalışanların gerçekten iş doyumlarını etkileyen İSG faktörlerini tespit etmede önemli ayrıntılara ulaşılması açısından önemli olabilecektir. Ayrıca, bölgedeki diğer iş seçeneklerinin varlığı maden çalışanlarının iş doyumlarında ve çalışma yaşamı kalitelerinde belirleyici olabilir. Söz konusu faktörlerin de bundan sonra yapılacak çalışmalar için incelenmesi önerilebilir. Ayrıca, böylesine zor bir alanda çalışan madencilerin işletmeleri için devamlılığın sağlanması, onların sağlık ve refah düzeylerinin sağlanması için eğitimlerin sık olarak tekrarlanması, maden içindeki güvenlik ve sağlık tedbirlerinin sürekli kontrol edilmesi, çalışanların bu tedbirlere uymalarının teşvik edilmesi gerekmektedir. Çünkü günümüz dünyasında bunlar işletmelerin karlılık ve etkinliğini arttıran faktörler olmaktan ziyade, artık etik ve sosyal zorunluluklarını da ifade etmektedir. 


\section{EXTENDED ABSTRACT}

\section{The Effect of Occupational Health and Safety Prac- tices on Job Satisfaction: The Mediator Role of Quality of Work Life}

Hasan Sadık Tatlı - Ahmet Melih Eyitmiş - Muhammet Zeki Zümrüt

Beykent University-Sütçü Imam University

It is thought that the occupational health and safety activities applied only to fulfill the procedures in the enterprises will not provide sufficient benefit to the employees and ultimately to the organizations. Based on this idea, it is aimed to determine the mediating role of the quality of working life in the effect of OHS practices on job satisfaction. Therefore, research is carried out in mining enterprises. It has been decided to research mining enterprises with the thought that mining works are very critical in terms of risk, the factors that will provide the job satisfaction of the employees are limited, and OHS practices will be different from other jobs in terms of increasing the quality of working life of the employees. The results to be obtained may be necessary for reconsidering the Classical Period research subject such as occupational health and safety in post-modern management studies and from different perspectives, determining the different relative effects of OHS practices, and creating research motivation risky sectors. In addition, the findings to be obtained are essential in determining what level of welfare the OHS practices in high-risk areas provide to the employees. The sample of the research consists of people working in a mining operation in Kütahya. Simple random sampling technique was used to determine the sample. The fact that each participant has an equal chance of participating in the research reduces the selection error due to the selection of the participants. In addition, the accessible listing of the sample is another advantage of the simple random sampling technique. Appropriate responses were received from 215 of the 330 mining workers reached within the scope of the research. Ethics committee approval was obtained from Beykent University, Publication Ethics Committee for Social and Human Sciences 
on 25.01.2021 to determine the suitability of the survey data collection tools of the research.

The research hypotheses are as follows;

$\mathrm{H}_{1}$ : OHS practices affect job satisfaction positively.

$\mathrm{H}_{2}$ : Quality of work-life positively affects job satisfaction.

$\mathrm{H}_{3}$ : OHS practices affect the quality of working life positively.

$\mathrm{H}_{4}$ : Quality of work-life mediates the relationship between OHS practices and job satisfaction.

$\mathrm{H}_{4 a}$ : Quality of work-life mediates the relationship between personal motivation for safety and job satisfaction.

$\mathrm{H}_{4 b}$ : Quality of work-life mediates the relationship between positive safety practice and job satisfaction.

$\mathrm{H}_{4 c}$ : Quality of work-life mediates the relationship between fatalism and job satisfaction.

$\mathrm{H}_{4 \mathrm{~d}}$ : Quality of work-life mediates the relationship between risk rationale and job satisfaction.

$\mathrm{H}_{4 \mathrm{e}}$ : Quality of work life mediates the relationship between optimism and job satisfaction.

$\mathrm{H}_{4 \mathrm{f}}$ : Quality of work-life mediates the relationship between perceived safety and job satisfaction.

In order to determine the intermediary role in the research, the SPSS Process 2.16 macro, which is integrated with the SPSS 25 package program, was used. Many models are available in this macro. The research model is compatible with model 4 created by Hayes (2018). For this reason, the mediation analysis was carried out on model number 4 . In addition, the procedure of Hayes (2018) was followed in the interpretation of the analyzes.

Willamson et al. (1997) created the occupational health and safety scale, and the scale consists of 32 items and six dimensions. Researches conducted by Atay (2006), Bayer and Günal (2018) were used to create the Turkish form of the scale. Sirgy et al. (2001) created the quality of work-life scale and consisted of 16 items. The Turkish form of the working life scale was obtained from the study conducted by Taşdemir Afşar (2011). Finally, the job satisfaction scale was used in the form created by Wright and Cropanzano (1998) and translated into Turkish by Rizaoğlu and Ayyldiz (2008). There are five items in the measurement tool. The 
survey questions were prepared in a 7-point Likert type (1=Strongly Disagree, $7=$ Strongly Agree).

As a result of the research, some findings were reached; OHS practices applied in mines increase the life satisfaction of employees. In addition, OHS practices increase the quality of working life. Therefore, it has been determined that the quality of working life has a mediating role in increasing the employees' job satisfaction in the OHS practices applied in the mines. So that; If OHS practices provide a quality of working life, it becomes an essential result that the job satisfaction of the employees will increase. In other words, it is possible to state that the employees' job satisfaction will not increase when the OHS practices are not at a level to increase the working life quality of the mineworkers.

Some factors should not be ignored while evaluating the findings; Most of the workers are miners working for minimum wage, and the family income of the workers is also very low. Therefore, it may be appropriate to use different techniques to determine the factors affecting employees' job satisfaction in this situation. For example; In-depth interviews will be important in reaching important details in determining the OHS factors that employees' job satisfaction in complicated work areas such as mines. In addition, the existence of other job options in the region may be evident in the job satisfaction and quality of work-life of mine workers. Therefore, it can be recommended to examine these factors for future studies. In addition, in order to ensure continuity for the businesses of miners working in such a complex area, to ensure their health and welfare, the training should be repeated frequently, the safety and health measures in the mine should be constantly checked, and the employees should be encouraged to comply with these measures. Because these factors now express ethical and social obligations rather than factors that increase the profitability and efficiency of businesses today.

\section{Kaynakça/References}

Akkaya, M. A. (2017). Bilgi merkezlerinde iş sağlığı ve güvenliğinin önemi ve uygulanabilirliğine ilişkin bir durum değerlendirmesi. Türk Kütüphaneciliği, 31(4), 501-519. 
Aksoy Zor, E. (2019). Sinıf öğretmenlerinin umutsuzluk düzeyleri ile iş doyumla$r l$, iş yaşam kaliteleri ve tükenmişlik düzeyleri arasındaki ilişkinin incelenmesi. Yayınlanmamış Yüksek Lisans Tezi, Trabzon Üniversitesi, Lisansüstü Eğitim Enstitüsü.

Altay, M. ve Turunç, Ö. (2018). İş yükü, çalışma yaşamı kalitesi ve işten ayrılma niyeti ilişkisi: Lider üye etkileşiminin ve örgütsel bağlllı̆̆ın aracılık rolü. Kafkas Üniversitesi İktisadi ve İdari Bilimler Fakültesi Dergisi, 9(17), 191-229.

Atay, F. (2006). Endüstri alanında çalışan bireylerin iş doyumu düzeylerinin iş güvenliği algıları açısından incelenmesi. Yayınlanmamış Yüksek Lisans Tezi, Sosyal Bilimler Enstitüsü, Sakarya Üniversitesi, Sakarya.

Aydın, İ., Çelik, Y. ve Uğurluoğlu, Ö. (2011). Sağlık personeli çalışma yaşamı kalitesi ölçeği: Geliştirilmesi, geçerliliği ve güvenilirliği. Toplum ve Sosyal Hizmet, 22(2), 79-100.

Balkır, Z. G. (2012). İş sağlı̆̆ı ve güvenliği hakkının korunması: İşverenin iş sağlığ1 ve güvenliği organizasyonu. SGD-Sosyal Güvenlik Dergisi, 2(1), 56-91.

Bayer, E. ve Günal, D. (2018). Hemşirelerin iş sağllğı ve güvenliği algılarının incelenmesi. Mehmet Akif Ersoy Üniversitesi Sosyal Bilimler Enstitüsü Dergisi, 10(25), 503-519.

Biçerli, M. K., (2019). Çalışma ekonomisi. Beta Basım Yayım.

Bilgin, S., Yalçınöz Baysal, H. ve Hendekçi, A. (2019). Hastanede çalışan sağlık personelinin iş sağlığı ve güvenliğine yönelik görüşleri ile iş doyumlarının belirlenmesi. Sağlık ve Toplum, 29(2), 43-49.

Çınar, O. ve Gündoğdu, M. (2019). İş sağllğı-güvenliği, iş tatmini ve örgütsel bağlllık arasındaki ilişkinin incelenmesi: Erzurum ve İstanbul uygulaması. İş ve Hayat Dergisi, 5(9), 231-247.

Dayan, S. ve Öngel, V. (2016). İş sağlı̆̆ı ve güvenliği uygulamalarının sağlık çalışanları tarafından değerlendirilmesi: Bir özel hastane örneği. International Conference On Eurasian Economies, 4, 479-486.

Demir Erbil, D. ve Çopur, Z. (2018). Zaman yönetimi, çalışma yaşamı kalitesi ve iş doyumu ilişkisinin incelenmesi. Zeugma I. Uluslararası Multidisipliner Çalışmalar Kongresi, 152-169.

Dhamija, P., Gupta, S. and Bag, S. (2019). Measuring of job satisfaction: The use of quality of work life factors. Benchmarking: An International Journal, 26(3), 871-892. 
Erdem, B. ve Kaya, İ. (2013). Çalışma yaşamı kalitesini etkileyen faktörlerin işgörenler tarafından algılanması: Otel çalışanları üzerinde bir araştırma. Dumlupinar Üniversitesi Sosyal Bilimler Dergisi, 35, 135-150.

Gamal, N. L., Taneo, S. Y. M. and Halim, L. (2018). Job satisfaction as a mediation variable in the relationship between work safety and health (k3) and work environment to employee performance. Jurnal Aplikasi Manajemen, 16(3), 486-493.

George, D. and Mallery, M. (2010). Spss for Windows step by step: A simple guide and reference. 17.0 update (10a ed.), Pearson.

Hair, J., Black, W., Babin, B. and Anderson, R. (2014). Multivariate data analysis. 7. Ed. Pearson Education Limited.

Hayes, A. F. (2018). Introduction to mediation, moderation, and conditional process analysis: A regression-based perspective (2nd ed.). New York, NY: The Guilford Press.

Jaben, F., Friesen, H. L. and Ghoudi, K. (2017). Quality of work life of Emirati women and its influence on job satisfaction and turnover intention: Evidence from the UAE. Journal of Organizational Change Management, 31(2), 352-370.

Karaahmetoğlu, A. (2019). 6331 sayılı iş sağlığı ve güvenliği kanunu bağlamında Soma madenlerinin iş sağlığ 1 ve güvenliği açısından değerlendirilmesi. Sosyal Siyaset Konferanslarn Dergisi, 76, 89-128.

Karakaya Çiçek, H. ve Çoruk, A. (2017). İlköğretim okullarında görev yapan öğretmenlerin okul yaşam kalitesi algıları ile iş doyumu algıları arasındaki ilişki. Dicle Üniversitesi Eğitim Bilimleri Fakültesi, 31, 750-761.

Karcıoğlu, F. ve Bakan, S. (2016). İş sağlığı ve güvenliği uygulamalarının düzeyi ile iş tatmini arasındaki ilişki. Atatürk Üniversitesi İktisadi Ve İdari Bilimler Dergisi, 31(5), 1289 - 1299.

Kırel, Ç. (1999). Esnek çalışma saatleri uygulamalarında cinsiyet, iş tatmini ve iş bağllı̆̆g ilişkisi. İstanbul Üniversitesi İşletme Fakültesi Dergisi, 28(2), 115-138.

Koçel, T. (2015). İşletme yöneticiliği. Genişletilmiş 15. Baskı, Beta Yayıncllık, İstanbul.

Marşap, A. (2007). İşletmelerin iş ve yaşam kalitesini artırmaya yönelik iklim değişimlerine duyarlılı̆̆ının artan önemi. 38. ICANAS, Ankara-Türkiye, 629-642.

Öngel, G. (2019). İş, aile ve çatışma. İstanbul:A Kitap. 
Rızaoğlu, B. ve Ayyıldız, T. (2008). Konaklama işletmelerinde örgüt kültürü ve iş tatmini: Didim örneği. Anatolia: Turizm Araştırmaları Dergisi, 19(1), 7-20.

Saraç, Ç. K. (2016). İşs sağll̆̆g ve güvenlik kültürü algısının iş tatmini ile ilişkisinin incelenmesi. Yüksek Lisans Tezi. Nişantaşı Üniversitesi Sosyal Bilimler Enstitüsü, İstanbul.

Saraji, G. N. and Dargahi, H. (2006). Study of quality of work life (QWL). Iranian Journal of Public Health, 35(4), 8-14.

Sirgy, M. J., Efraty, D., Siegel, P. and Lee, D. J. (2001). A new measure of quality of work life (QWL) based on need satisfaction and spillover theories. Social Indicators Research, 55(3), 241-302.

Sobel, M. E. (1982). Asymptotic confidence intervals for indirect effects in structural equation models. Sociological Methodology, 13, 290-312.

Sobel, M. E. (1986). Some new results on indirect effects and their standard errors in covariance structure. Sociological Methodology, 16, 159-186.

Şimşek, M. Ş. ve Çelik, A. (2016). İ̧̧letme Bilimine Giriş. Eğitim Yayınevi.

Şimşek, S., Ağseren, S. ve Şimşek, H. (2020). İş sağllğ ve iş güvenliği uygulamalarında sensör kullanımının incelenmesi. İstanbul Aydın Üniversitesi Dergisi, 12(1), 41-53.

Tabachnick, B. G. and Fidell, L. S. (2013). Using multivariate statistics (sixth ed.). Pearson.

Taşdemir Afşar, S. (2011). Çalışma yaşamı kalitesinin örgütsel bağllık düzeyi üzerindeki etkisi: Devlet ve vakı üniversitelerinde çalışan akademisyenler üzerine nicel bir araştırma. Doktora Tezi, Sosyal Bilimler Enstitüsü, Hacettepe Üniversitesi, Ankara.

Tatlıcan, M ve Çögenlin, M. Z. (2020). İş sağlığı ve güvenliği performans değerlendirme uygulamalarının iş tatmini üzerine etkisi: Endüstri işletmesi örneği. Uşak Üniversitesi Sosyal Bilimler Dergisi, 13(1), 181-194.

Turunç, Ö., Tabak, A., Şeşen, H. ve Türkyılmaz, A. (2010). Çalışma yaşamı kalitesinin prosedür adaleti, iş tatmini, iş stresi ve işten ayrılma niyetine etkisi. "İs, Güç" Endüstri İlişkileri ve İnsan Kaynakları Dergisi, 12(2), 115-134.

TÜIKK, (2013). İş kazaları ve işe bağlı sağlık problemleri araştırma sonuçları. Ankara: TUIK

Türkay, O. (2015). Çalışma yaşamı kalitesinin iş memnuniyeti ve bağlılık üzerine etkileri: Seyahat acentaları üzerine bir araştırma. Celal Bayar Üniversitesi İ̈BF, Yönetim ve Ekonomi, 22(1), 239-256. 
Umutlu, S. ve Karcıoğlu, F. (2021). İş sağlığı ve güvenliğinin iş tatmini üzerine etkisi: Çimento sektöründe bir uygulama. Süleyman Demirel Üniversitesi İktisadi ve İdari Bilimler Fakültesi Dergisi, 26(1), 65-81.

Willamson, A. M., Feyer, A. M., Caims, D. and Biancotti, D. (1997). The development of a mesure of safety climate: The role of safety perceptions and attitudes. Safety Science, 2, 15-27.

Wright, T. A. and Cropanzano, R. (1998). Emotional exhaustion as a predictor of job performance and voluntary turnover. Journal Of Applied Psychology, 83(3), 486-493.

Yıldırım, İ., Akyüz, K. C., Akyüz, İ. ve Alevli, C. (2015). Mobilya sektöründe çalışanların iş güvenliği algıları ve iş doyumu düzeylerinin incelenmesi. 3. Ulusal Mobilya Kongresi, Selçuk Üniversitesi, Selçuk Teknik Dergisi Özel Sayısı, 171-184.

Yıldız, N., Yolsal, N., Ay, P. ve Kıyan, A. (2003). İstanbul Tıp Fakültesi'nde çalışan hekimlerde iş doyumu. İstanbul Tip Fakültesi Mecmuası, 66(1), 34-41.

Yusuf, R. M., Eliyana, A. ve Sari, O. N. (2012). The influence of occupational safety and health on performance with job satisfaction as intervening variables (Study on the production employees in PT. Mahakarya Rotanindo, Gresik). American Journal of Economics, 6, 136-140.

\section{Kaynakça Bilgisi / Citation Information}

Tatlı, H. S., Eğitmiş, A. M., ve Zümrüt, M. Z. (2021). İş sağlı̆̆1 ve güvenliği uygulamalarının iş doyumuna etkisi: Çalışma yaşamı kalitesinin aracılık rolü. OPUS-Uluslararası Toplum Araştırmaları Dergisi, 18(Yönetim ve Organizasyon Özel Sayısı), 1256-1284. DOI:10.26466//opus.892070. 